\title{
A few remarks on the Inedita Pseudo-Chrysostomic Homily De transfiguratione et eleemosyna (CPG 5009; BHGn 1996t)
}

\begin{tabular}{|c|c|}
\hline \multicolumn{2}{|c|}{$\begin{array}{l}\text { Author: } \\
\text { Radu Gârbacea }{ }^{1,2}\end{array}$} \\
\hline \multicolumn{2}{|c|}{$\begin{array}{l}\text { Affiliation: } \\
{ }^{1} \text { Department of Orthodox } \\
\text { Theology, Faculty of } \\
\text { Orthodox Theology, Lucian } \\
\text { Blaga University of Sibiu, } \\
\text { Sibiu, Romania }\end{array}$} \\
\hline \multicolumn{2}{|c|}{$\begin{array}{l}{ }^{2} \text { Department of Systematic } \\
\text { and Historical Theology, } \\
\text { Faculty of Theology and } \\
\text { Religion, University of } \\
\text { Pretoria, Pretoria, South Africa }\end{array}$} \\
\hline \multicolumn{2}{|c|}{$\begin{array}{l}\text { Research Project Registration: } \\
\text { Project Leader: J. Pillay (D) } \\
\text { Project Number: } 04653484\end{array}$} \\
\hline \multicolumn{2}{|c|}{$\begin{array}{l}\text { Description: } \\
\text { The author is participating as } \\
\text { the research associate of Dean } \\
\text { Prof. Dr Jerry Pillay, Faculty of } \\
\text { Theology and Religion, } \\
\text { University of Pretoria. }\end{array}$} \\
\hline \multicolumn{2}{|c|}{$\begin{array}{l}\text { Corresponding author: } \\
\text { Radu Gârbacea, } \\
\text { radu_garbacea@yahoo.com }\end{array}$} \\
\hline \multicolumn{2}{|c|}{$\begin{array}{l}\text { Dates: } \\
\text { Received: } 02 \text { Apr. } 2021 \\
\text { Accepted: } 18 \text { June } 2021 \\
\text { Published: } 27 \text { Aug. } 2021\end{array}$} \\
\hline \multicolumn{2}{|c|}{$\begin{array}{l}\text { How to cite this article: } \\
\text { Gârbacea, R., 2021, 'A few } \\
\text { remarks on the Inedita } \\
\text { Pseudo-Chrysostomic Homily } \\
\text { De transfiguratione et } \\
\text { eleemosyna (CPG 5009; } \\
\text { BHGn 1996t)', HTS Teologiese } \\
\text { Studies/ Theological Studies } \\
77(4) \text {, a6686. https://doi. } \\
\text { org/10.4102/hts.v77i4.6686 }\end{array}$} \\
\hline \multicolumn{2}{|c|}{$\begin{array}{l}\text { Copyright: } \\
\text { (c) 2021. The Authors. } \\
\text { Licensee: AOSIS. This work } \\
\text { is licensed under the } \\
\text { Creative Commons } \\
\text { Attribution License. }\end{array}$} \\
\hline \multicolumn{2}{|l|}{ Read online: } \\
\hline 回品罗 & $\begin{array}{l}\text { Scan this QR } \\
\text { code with your } \\
\text { smart phone or } \\
\text { mobile device } \\
\text { to read online. }\end{array}$ \\
\hline
\end{tabular}

The article presents the preliminary results of the author's study of the unedited homily De transfiguratione et eleemosyna (CPG 5009; BHGn 1996t), ascribed to John Chrysostom. The question of the manuscript tradition is first discussed. The article shows that Maurice Sachot is right when he indicates only the manuscript Romanus Angelicus gr. 125 (T.1.7) as a manuscript witness of this homily and that the other two witnesses indicated by Pinakes are erroneous. Then, the descriptions of the folios that preserve the homily are analysed in the light of a new examination of them. This re-examination shows that hitherto several sources that inspired the compiler have gone unnoticed. This is followed by a brief summary of the contents of the homily and an analysis of the passages in which almsgiving is mentioned.

Contribution: The article offers a re-examination of the folios 353v-361 from the manuscript Romanus Angelicus gr. 125 (T.1.7), the first presentation of the content of the homily De transfiguratione et eleemosyna, and tries to shed light on the association of the theme of the Transfiguration with almsgiving.

Keywords: Pseudo-John Chrysostom; John Chrysostom; De transfiguratione et eleemosyna; CPG 5009; BHGn 1996t; codex Romanus Angelicus gr. 125 (T.1.7); Transfiguration; almsgiving.

\section{Introduction}

The manuscript tradition assigns to Saint John Chrysostom ( $\dagger$ 407) homilies that were not composed by him. ${ }^{1}$ Many of them are still unedited (Geerard 1974:615-651). ${ }^{2}$ Amongst these, we find the homily De transfiguratione et eleemosyna (CPG 5009; BHGn 1996t). This homily distinguishes itself from other patristic and Byzantine homilies that comment on the Transfiguration episode, as related by Matthew (17:1-9), Mark (9:2-9) and Luke (9:28-36), by the title under which it was

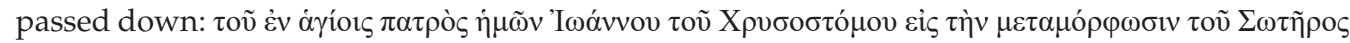

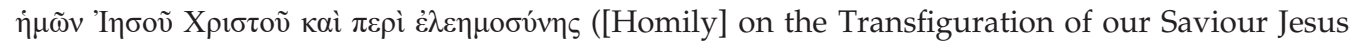
Christ and on Almsgiving of our Father Amongst the Saints John Chrysostom). With one exception, all the other patristic and Byzantine homilies that we know concerning this episode were passed

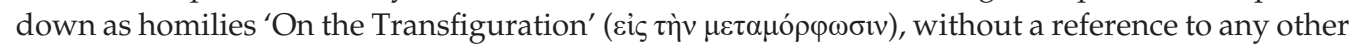
subject matter (Sachot 1981:16-17). ${ }^{3}$ The association between the two themes, Transfiguration and almsgiving, in De transfiguratione et eleemosyna, might be motivated by the fact that, from early on, the Transfiguration was interpreted as a revelation of the eschatological reality related to Christ's Second Coming, the end of the world and the Son of God's manifestation in radiant glory as an eschatological Judge (Ică jr 2007a:12, 2007b:64). For example, the author of Peter's Apocalypse (c. 135, Egypt) perceives a strong correlation between the narrative of the Transfiguration and Christ's eschatological speech. He fuses the narrative of the Transfiguration episode with the address on the Mount of Olives in such a manner that the Transfiguration becomes a part of the latter episode in which Christ revealed the destiny of the faithful at the Parousia (Lee 2009:160). According to Christ's address in Matthew 25:31-46, no one may enter the Kingdom of Heaven without giving alms.

\footnotetext{
1.Repertoria of these homilies may be found in De Aldama (1965) and Geerard (1974:540-615). As a result of some thorough analyses of direct and indirect witness of manuscript tradition in style and vocabulary, some of them were reattributed to other patristic authors.

2.The progress made within the period 1974-1998 in the direction of publishing these 'inedita' homilies may be traced in the work of Geerard and Noret (1998:322-338). Within the same sources, one may trace also the new 'inedita Chrysostomica' (336-338). On the Geerard and Noret (1998:322-338). Within the same sources, one may trace also the new 'inedita Chrysostomica' (336-338). On the
importance of research on works transmitted under the name of John Chrysostom for the Orthodox tradition, see Buda (2012:XV-XVII).

3.The exception is the homily passed down under the name of Timothy of Jerusalem/Antioch, In crucem et in transfigurationem (CPG

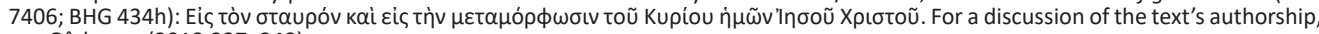
see Gârbacea (2018:237-248).
}

Note: Special Collection: Lucian Blaga University, Sibiu, Romania, sub-edited by Daniel Buda (Lucian Blaga University) and Jerry Pillay (University of Pretoria). 
This article aims to present the preliminary results of the editing project of the homily De transfiguratione et eleemosyna. Matters related to the passing down of the text, its composition and content, as well as passages mentioning almsgiving, are approached further on.

\section{Manuscript tradition}

According to the manuscript tradition inventory of the homilies on the Transfiguration drawn up by Sachot, the present homily was kept in a unique manuscript, codex Romanus Angelicus gr. 125 (T.1.7), centuries XI/XV, folios 353v-361 (1987:121). ${ }^{4}$ In consonance with the terminology and classification of liturgical collections proposed by Ehrhard in his monumental work, Überlieferung und Bestand der hagiographischen und homiletischen Literatur der griechischen Kirche von den Anfängen bis zum Ende des 16. Jahrhunderts, the codex is a Panegyrikon, type A (1938:3). ${ }^{5}$ This type of collection contains readings both for fixed feasts and for movable feasts but in unequal proportion. The number of homilies for movable feasts is habitually greater than Saints' lives and homilies for fixed feasts. Type A begins on September 8 with readings for the Nativity of the Virgin Mary. After this, the structure is similar to that of the lectionaries (Jahressammlungen) type $\mathrm{A}$, which begin on September 1 and continue with a selection of readings for fixed feasts until February, after which the movable year is included, from the beginning of Lent to the Sunday after Pentecost. The collection continues with readings for fixed feasts until August 29 (the Beheading of St. John the Baptist) (Ehrhard 1937:154). The homily is preceded (folios 343v-353v) by In ss. Petrum et Heliam (CPG 4513; BHGn 1488), attributed to John Chrysostom and is followed (folios 361-362v) by a fragment from the homily In dormitionem s. Mariae homilia II, attributed to Andrew of Crete (CPG 8182; BHGa 1115).

On 10 March 2021, the Pinakes database, managed by the Research and History of Texts Institute (Institut de Recherche et d'Histoire des Textes), indicated another two codices that contain the homily, besides codex Romanus Angelicus gr. 125 (T.1.7). These were codex Reginensis graecus 45, XVI century, folio 79r-v and codex Athous Dionysiou 169 (Lambros 3703), XVI century, folios $421-429 \mathrm{v} .{ }^{6}$ The two codices' indication as manuscript witnesses do not seem to be supported either by Stevenson or Ehrhard. The description of codex Reginensis graecus 45, offered at the end of XIX century by Stevenson, does not mention the preservation in this codex of a homily with such a title (Stevenson 1888:35-38). About folio 79r-v, Stevenson writes: 'Ex Chrysostomo? De poenitentia, inc.

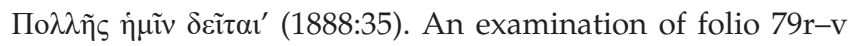
from the Vatican manuscript reveals that the homily starting

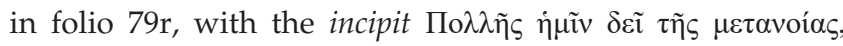

4.For a description of this codex, see De' Cavalieri and Muccio (1896:164-168) Ehrhard (1938:33-34) and Carter $(1983: 177,244)$. The manuscript may be viewed online: Multimedia viewer (internetculturale.it), last accessed on 10.03.2021.

5.The categories are set out in Leroy (1967:34-36).

6.Pinakes | Пívakes - Notice: lohannes Chrysostomus, De transfiguratione et eleemosyna (cnrs.fr), last accessed on 10.03.2021. $\dot{\alpha} \gamma \alpha \pi \eta \tau o i ̀, \pi 0 \lambda \lambda \tilde{\eta} \varsigma \tau \tilde{\eta} \varsigma \varepsilon \cup ̉ \chi \tilde{\eta} \varsigma, \pi 0 \lambda \lambda \tilde{\eta} \varsigma \tau \tilde{\eta} \varsigma \kappa \alpha \rho \tau \varepsilon \rho i ́ \alpha \varsigma, \pi 0 \lambda \lambda \tilde{\eta} \varsigma \tau \tilde{\eta} \varsigma$

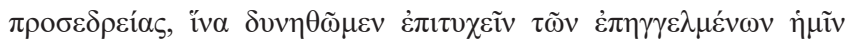
$\dot{\alpha} \gamma \alpha \theta \tilde{\omega} v$, is, in fact, a fragment from the homily 27 In epistulam ad Hebraeos (Migne 1862:63:190 ab 1.26). Ehrhard also does not mention the passing down of a homily with the title De transfiguratione et eleemosyna in his descriptions of the codex Reginensis graecus 45 (1943:609-611). Similarly, the list of codex Athous Dionysiou 169 (Lambros 3703), XVI century, folios $421-429 \mathrm{v}$ as a manuscript witness is an error. The text preserved in these folios, which has the incipit Ei $\tau 1 \varsigma \dot{v} \mu \tilde{\omega} v, \tilde{\omega}$

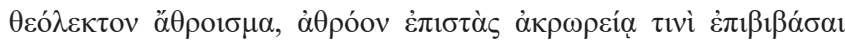
$\kappa \alpha \theta v \pi \imath \sigma \chi v \varepsilon i \tau o$, is nothing more than the homily In transfigurationem Domini (CPG 4898; BHG 1980k), an incorporation of the BHGn 1984bd version of homily 56 In Matthaeum by John Chrysostom (Ehrhard 1943:157; Sachot 1983:123-146, 1987:110).

\section{The composition of the text and its content}

Giorgio Muccio, who was the first to describe the codex Romanus Angelicus gr. 125 (T.1.7), also made the first observations on the composition of the homily. According to him, the homily contains several fragments from authentically Chrysostomic homilies, compiled as follows: the homily begins (folio 353v) with a fragment, which is the very beginning of homily 39 In Iohannem (Migne 1862:59:219.28-47); it continues (folio $354 \mathrm{v}$ ) with the beginning of homily 23 In Iohannem (Migne 1862:59:137-139), followed by an interpretation of the Transfiguration episode, and is concluded (folio 359v) with a fragment, with a few elements omitted, from homily 11 In epistulam ad Romanos (Migne 1862:60:491-494) (De' Cavalieri \& Muccio 1896:168).

The information presented by Muccio was adopted by both Halkin and Carter. In his augmented versions of Bibliothecae Hagiographicae Graecae, published in 1969 and 1984, Halkin summarised the description of the content of De transfiguratione et eleemosyna as follows: 'Excerpta ex hom. 39 et 23 in Ioannem et 11 in Romanos' (ed. Halkin 1969:326, 1984:379-380). In their inventories, Sachot (1987:121) and Geerard (1974:640) accepted the information given by Halkin, without further investigation. In 1983, in volume 5 of Codices Chrysostomici Graeci, Carter reproduced the observations of and Muccio as follows:

In transfigurationem homilia composita. In Iohannem homilia 39: M. 59, 219 usque ad lin. 18 ab imo. In Iohannem homilia 23: M. 59, 137-139, lin. 1 In Epistulam ad Romanos homilia 11: M. 60, 491, lin. 3 ab imo-494. (p. 244)

The descriptions of the text do not allow us to say much about the composition and content of De transfiguratione et eleemosyna. What we know may be summarised in the following way: we know a unique manuscript witness; we know that the homily is a composite text, making use of three authentic Chrysostomic homilies; and we also know that the first two fragments succeed one another and that the homily is concluded with another Chrysostomic fragment. 
Yet, we know nothing about the coherence of the text and the manner in which the author discusses the almsgiving theme announced in the title.

The examination of folios 353v-361r from codex unicum Romanus Angelicus gr. 125 (T.1.7) offers a few surprises about the textual composition of De transfiguratione et eleemosyna. Also, the descriptions that we have at our disposal support some observations:

1. The beginning of the homily (folio 353v) is almost identical with the beginning of Homily 39 on John by John Chrysostom (Migne 1862:59:219.28-47). ${ }^{7}$

2. The homily continues (folios $353 \mathrm{v}-354 \mathrm{v}$ ) with another Chrysostomic text, the beginning of Homily 23 on John (Migne 1862:59:137.40-139.2), ${ }^{8}$ which, in contrast to the first fragment, is a little longer. It extends from the second column of folio $353 \mathrm{v}$ up to the beginning of the second column of folio $354 \mathrm{v}$, when the author passes to the very interpretation of the Transfiguration episode:

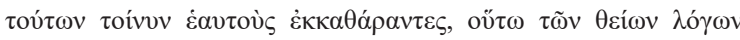

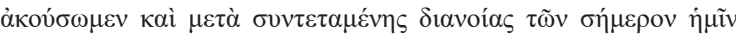

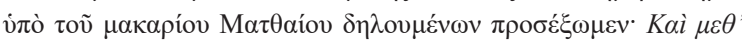

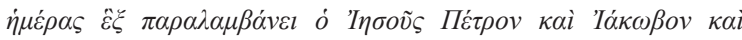

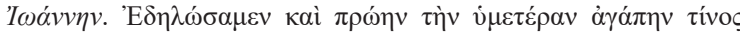

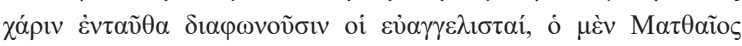

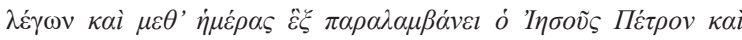

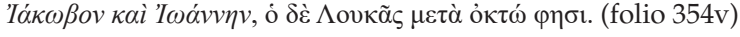

[W]ashing ourselves, therefore, of these, let us listen to the godly words and with an attentive mind let us keep in mind those today narrated by blessed Matthew: Now after six days, Jesus took Peter, James and John. [Author's own translation]

3. The interpretation of the biblical narrative of the Transfiguration (folios $354 \mathrm{v}-356 \mathrm{r}$ ) is inspired by the homily De capto Eutropio (CPG 4528) attributed to John Chrysostom $^{9}$ and by the homily In transfigurationem Domini (CPG 5807; BHGa 1980) attributed to Proclus of Constantinople, a fact which has passed unnoticed and which I have recently pointed out (Gârbacea forthcoming). As an example, I present a passage in folio 355v, comparing it with the text of the homily In transfigurationem Domini published in Patrologia Graeca 65, where Riccardi's edition (ed. 1630:297-303) is reproduced. (See Table 1.)

4. The text continues (folios 356r-359v) with another Chrysostomic fragment, which has also remained unidentified before now. The long fragment comes from John Chrysostom's Homily 9 on Romans (Migne 1862:60:471.35-474.24). As an example, I hereby present the beginning of the text in folios 356r-356v, comparing it to the text of Homily 9 on Romans from the Migne edition. (See Table 2.)

7.Homily 39 interprets the text in John 5:22-23: 'The Father doesn't judge anyone, but He has made the Son the Judge of everyone'.

8. Homily 23 interprets the text in John 2:11: 'This was Jesus' first miracle and he did it in the village of Cana in Galilee'.

9.The editors of Clavis Patrum Graecorum placed the homily amongst the homilies whose Chrysotomic authorship is uncertain. Cameron argues in favour of Chrysostomic authenticity (Cameron 1988:34-48).

TABLE 1: A passage in folio $355 \mathrm{v}$ and text of the homily In transfigurationem Domini (CPG 5807; BHGa 1980).

Romanus Angelicus gr. 125 (T.1.7), Migne 1862:65:764CD-765A

folio 355v

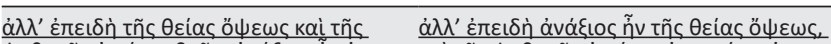

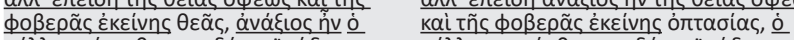

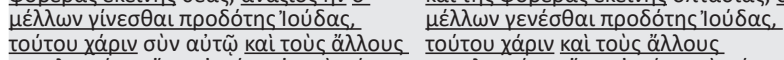

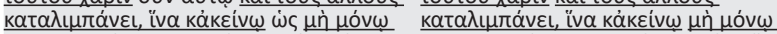

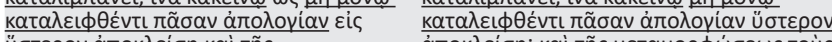

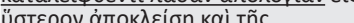

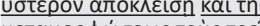

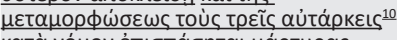

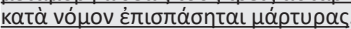
a

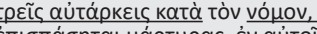
घuxn் kai

TABLE 2: A passage in folios 356r-356v and text from John Chrysostom's Homily 9 on Romans.

Romanus Angelicus gr. 125 (T.1.7), folios Migne 1862:60:471.35-41

356r-356v

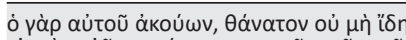

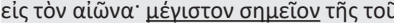

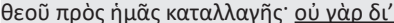

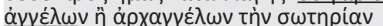

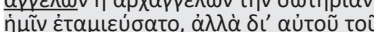

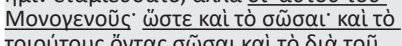

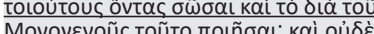

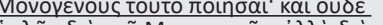

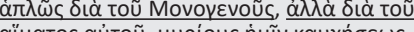

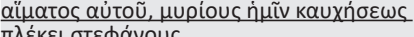
$\pi \lambda \varepsilon \dot{k \varepsilon l ~ \sigma \tau \varepsilon \phi a ́ v o u s . ~}$

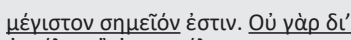

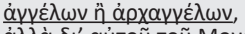
$\dot{\alpha} \lambda \lambda \dot{\alpha} \delta \iota^{\prime}$ aútoũ toũ Movovevoũc

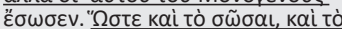

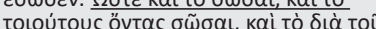
Movovevoũc toũto roñ̃

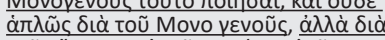

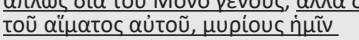

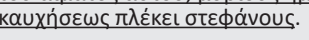

5. The last part of the homily (folios 359v-361r) summarises and reproduces word by word fragments from John Chrysostom's Homily 11 on Romans (Migne 1862:60:491. 58-494.33).

The content of the homily might be summarised as follows: the audience is made to pay attention to the fact that 'our existence is not limited to things on earth', that 'another life is awaiting us after this one' and that 'we will sit in front of a frightening Trial Court of Judgment'. Thinking continuously of this trial is of great use in inspiring us to perform acts of virtue. In support of this statement on the relation between thinking about death and virtuous deeds, a text from The Wisdom of Sirach 7:36 is invoked: 'Remember thy end and thou shalt never sin!' At the same time, the listeners' attention is drawn to the fierceness and power with which the devil attacks, wishing to besiege the soul of man. As the devil's assaults come unexpectedly, there is a need for vigilance and watchfulness. Intemperance is the wound and disease that the devil provokes in his assaults. Through his words, the author wants to offer a cure for such diseases. After this long introduction, we find the interpretation of the Transfiguration episode. After an

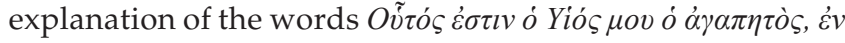

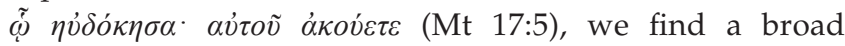
exposition of the reason why God 'did not save us through either angels or archangels, but through His only Begotten Son': 'God loved us'. That is why we must 'love the One Who loves us'. By loving us, He does not want us to walk on 'the road to evil', and with this purpose He steps into our lives, often permitting that we suffer and undergo hardships, and yet there is nothing that cannot be conquered by the one who loves God. To this, there follows a question: 'How do we show love and friendship to God?' The author then tries to answer this question during the last part of the homily.

10.aútó́pкเৎ cod. 


\section{On almsgiving}

The word $\dot{\varepsilon} \lambda \varepsilon \eta \mu \circ \sigma v ́ v \eta$ (almsgiving) appears once in the title of the homily and three times in the text (folios 354r, 359v and $360 \mathrm{v}$ ). The first reference to almsgiving is found in the fragment from Homily 23 on John. It is mentioned there in a context in which the preacher explains to his audience why his talks are varied in subject matter, enumerating a few of the themes he uses in his sermons: 'I now condemn greed, then delight; at another time I will refer to debauchery, and at some other time I will praise almsgiving and urge you

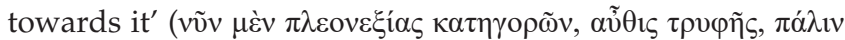

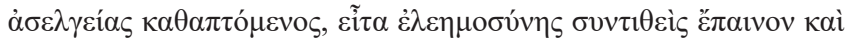
$\pi \alpha \rho \alpha ́ \kappa \lambda \eta \sigma ı v ;$ folio 354r).

The second reference to almsgiving is found in the answer to

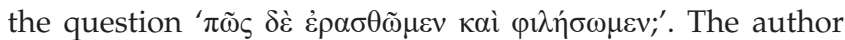
tells us that the love of God and friendship towards Him are shown 'through good deeds, a righteous life, and almsgiving

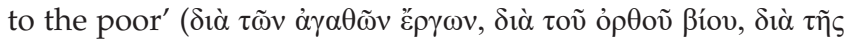

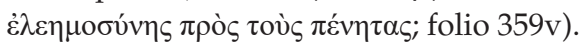

The third reference is presented towards the end of the homily, where the author speaks about what it is most important to adorn:

[Y]ou adorn the [house] walls, the floor and furniture and all the rest, and you do not practise almsgiving heartily, nor do you practise another way of life and do nothing more than the first, or you do even worse than the first. [Author's own translation]

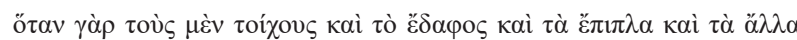

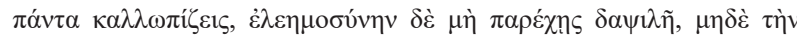

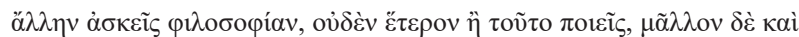
$\pi \mathrm{o} \lambda \lambda \tilde{\omega} \chi \alpha \lambda \varepsilon \pi \omega ́ \tau \varepsilon \rho o v ;$ folio 360v.

\section{Conclusion}

The examination of the folios from the manuscript Romanus Angelicus gr. 125 (T.1.7) that pass down the homily De transfiguratione et eleemosyna revealed a number of elements that had been previously unobserved. This was a remarkable omission given the scholarly reputation of those who had presented descriptions of the manuscript and proves the need to re-examine old descriptions, having now at our disposal quality copies of the manuscripts and instruments that researchers did not have a few decades ago.

With regard to the content of the text, at least two elements are astonishing: firstly, the space granted to the interpretation of the biblical narrative itself, which only slightly exceeds the introduction in length, and secondly the discussion on almsgiving, which occurs very late in the text and is very brief. Although the title of the homily announces a treatment of the Transfiguration episode and the almsgiving theme, they do not form the core of his lecture but rather act as prompts for the consideration of other themes. Thus, we may wonder if this might be the reason why the homily does not enjoy a richer manuscript tradition.

A third reflection concerns the reception of the authorship of the homily In transfigurationem Domini (CPG 5807; BHG
1980). It is known that this homily on the Transfiguration is passed down by the manuscript tradition both under Proclus' name and under John Chrysostom's name (Leroy 1967:100 105). Bearing in mind that the fragments he uses are from Chrysostomic homilies, it is most probable that the manuscript at the disposal of the compiler had ascribed the homily to Chrysostom, and the compiler himself had considered John Chrysostom to be the homily's author.

\section{Acknowledgements Competing interests}

The author declares that he has no financial or personal relationships that may have inappropriately influenced him in writing this article.

\section{Author's contributions}

R.G. is the sole author of this research article.

\section{Ethical considerations}

This article followed all ethical standards for research without direct contact with human or animal subjects.

\section{Funding information}

This research received no specific grant from any funding agency in the public, commercial or not-for-profit sectors.

\section{Data availability}

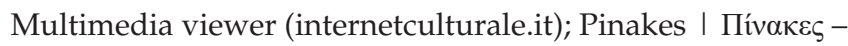
Notice: Iohannes Chrysostomus, De transfiguratione et eleemosyna (cnrs.fr).

\section{Disclaimer}

The views and opinions expressed in this article are those of the author and do not necessarily reflect the official policy or position of any affiliated agency of the author.

\section{References}

Buda, D., 2012, 'Vorwort oder Zur Bedeutung der Chrysostomosforschungen Adolf Martin Ritters für die orthodoxe Tradition' [Foreword or on the importance of Adolf Martin Ritter's research on Chrysostom for the Orthodox tradition]', in A.M. Ritter (ed.), Studia Chrysostomica: Aufsätze zu Weg, Werk und Wirkung des Johannes Chrysostomus (ca. 349-407), STAC 71, pp. XI-XXI, Mohr Siebeck, Tübingen.

Cameron, A., 1988, 'A misidentified homily of Chrysostom', Nottingham Medieval Studies 32, 34-48. https://doi.org/10.1484/J.NMS.3.155

Carter, R.E., 1983, Codices Chrysostomici Graeci V: Codicum Italiae partem priorem Éditions du Centre national de la recherche scientifique, Paris.

De Aldama, J.A., 1965, Repertorium Pseudochrysostomicum, Documents, études et répertoires publiés par l'Institut de recherche et d'histoire des textes 10, Éditions du Centre national de la recherche scientifique, Paris.

De' Cavalieri, P.F. \& Muccio, G., 1896, 'Index codicum graecorum bibliothecae Angelicae', Studi Italiali di Filologia Classica 4, 7-184.

Ehrhard, A., 1937, Überlieferung und Bestand der hagiographischen und homiletischen Literatur der griechischen Kirche von den Anfängen bis zum Ende des 16. Jahrhunderts, Band I, Texte und Untersuchungen zur Geschichte der altchristlichen Literatur 50, J.C. Hinrichs Verlag, Leipzig.

Ehrhard, A., 1938, Überlieferung und Bestand der hagiographischen und homiletischen Literatur der griechischen Kirche von den Anfängen bis zum Ende des 16. literatur der griechischen Kirche von den Anfangen bis zum Ende des 16. altchristlichen Literatur 51, J.C. Hinrichs Verlag, Leipzig. 
Ehrhard, A., 1943, Überlieferung und Bestand der hagiographischen und homiletischen Literatur der griechischen Kirche von den Anfängen bis zum Ende des 16.
Jahrhunderts, Band III/1, Texte und Untersuchungen zur Geschichte der altchristlichen Literatur 52/1, J.C. Hinrichs Verlag, Leipzig.

Gârbacea, R., 2018, 'Omilia la Cruce și la Schimbarea la Față (BHG 434h; CPG 7406) și numele enigmaticului ei autor' [Homily on the Cross and the Transfiguration (BHG 434h; CPG 7406) and the name of its enigmatic author], Revista Teologică 100(3), 237-248.

Gârbacea, R., 2021, 'A new indirect witness to In Transfigurationem Domini (CPG 5807): Codex Romanus Angelicus gr. 125 (T.1.7)', Studia Patristica: Paper presented at the Eighteenth International Conference on Patristic Studies held in Oxford 2019, Peeters, Leuven, forthcoming.

Geerard, M., 1974, Clavis Patrum Graecorum II: ab Athanasio ad Chrysostomum, Brepols, Turnhout.

Geerard, M. \& Noret, J., 1998, Clavis Patrum Graecorum: Supplementum, Brepols, Turnhout.

Halkin, F. (ed.), 1969, Auctarium Bibliothecae Hagiographicae Graecae, Subsidia Hagiographica 47, Société des Bollandistes, Bruxelles.

Halkin, F. (ed.), 1984, Novum Auctarium Bibliothecae Hagiographicae Graecae, Subsidia Hagiographica 65, Société des Bollandistes, Bruxelles.

Ică jr, I.I., 2007a, 'Teologia taborică a Cuviosului Grigorie Sinaitul şi posibila ei iradiere in spatiul românesc cu traducerea Cuvântului inedit la Schimbarea la Față a Domnului nostru lisus Hristos' [Gregory of Sinai's Thabor theology and its possible echo in the Romanian space with a Romanian translation of his Homily on the Transfiguration of Our Lord Jesus Christ]', Tabor 1(1), 11-26.

Ică jr, I.I, 2007b, 'Exegeză, dogmatică şi mistică isihastă în teologia taborică a Sfântului Ioan Damanschinul' [Exegesis, dogmatic and hesychast mystic in the Thabor theology of St. John Damanscene]', Tabor 1(5), 61-77.
Lee, S.S., 2009, Jesus' transfiguration and the believers' transformation: A study of the transfiguration and its development in early Christian writings, Wissenschaftliche Untersuchungen zum Neuen Testament 2, Reihe 265, Mohr Wissenschaftliche
Siebeck, Tübingen.

Leroy, F.J., 1967, L'homilétique de Proclus de Constantinople: Tradition manuscrite, inédits, études connexes, Studi e testi, 247, Biblioteca Apostolica Vaticana, Città del Vaticano.

Migne, J.-P. (ed.), 1862, Patrologiae cursus completus: Series graeca, 162 vols., Migne, Paris.

Multimedia viewer (internetculturale.it).

Pinakes | Пívakєৎ - Notice: lohannes Chrysostomus, De transfiguratione et eleemosyna (cnrs.fr).

Riccardi, V. (ed.), 1630, Sancti Patris Procli Archiepiscopi Constantinopolitan Analecta, Rome.

Sachot, M., 1981, L'omélie pseudo-chrysostomienne sur la Transfiguration CPG 4724, BHG 1975: Contextes liturgiques, restitution à Léonce, prêtre de Constantinople, édition critique et commentée, traduction et études connexes, Peter Lang, Frankfurt am Main.

Sachot, M., 1983, 'Le réemploi de l'homélie 56 in Matthaeum de Jean Chrysostome (BHGa 1984) dans deux homélies byzantines sur la Transfiguration (BHG 1980k et 1985)' [The re-use of homily 56 in Matthaeum by John Chrysostom (BHGa 1984) in two Byzantine hon des Sciences Religieuses 57(2), 123-146. https://doi.org/10.3406/rscir.1983.2973

Sachot, M., 1987, Les homélies grecques sur la transfiguration: tradition manuscrite, Éditions du centre national de la recherche scientifique, Paris.

Stevenson, H. (Senior), 1888, Bibliothecae Apostolicae Vaticanae... Codices manuscripti graeci Reginae Suecorum et Pii PP. II, Vaticano. 